\title{
MARKET OF TRANSPORT SERVICES \\ - ATTEMPT AT STRUCTURAL-FUNCTIONAL IDENTIFICATION
}

ANNA WIKTOROWSKA-JASIK

\begin{tabular}{|c|c|}
\hline & $\begin{array}{l}\text { West Pomeranian University of Technology Szczecin, POLAND } \\
\text { e-mail: annawik@zut.edu.pl }\end{array}$ \\
\hline $\begin{array}{l}\text { RECEIVED } \\
\text { ACCEPTED }\end{array}$ & $\begin{array}{l}2 \text { February } 2016 \\
1 \text { April } 2016\end{array}$ \\
\hline $\begin{array}{l}\text { JEL } \\
\text { CLASSIFICATION }\end{array}$ & R4 \\
\hline KEYWORDS & market, transport services, sector of road transport, branches of transport \\
\hline ABSTRACT & $\begin{array}{l}\text { The article presents an attempt to identify the structural-functional system of the market of transport services. } \\
\text { The basic structure of this market as well as the scope of services of particular participants is presented. } \\
\text { The market of transport services has been analyzed as the basic level for the functioning of transportation } \\
\text { companies. The role of transport services in the functioning of companies is stressed, emphasizing their sig- } \\
\text { nificance in production-service processes. Particular attention was paid to services from the road transport } \\
\text { sector. These services were divided into segments due to their diversity as well as the object of transportation. } \\
\text { The article also refers to basic tendencies typical of the development of the market of transport services as } \\
\text { well as the impact of the development of motorized individual transport on the situation of the segment of public } \\
\text { passenger transportation performed using means of collective transport. }\end{array}$ \\
\hline
\end{tabular}

\section{Introduction}

The market of transport services should be presented as all economic relations, including commercial ones, taking place between its participants. It is characterized by a high degree of diversity in the structure and functions as well as high dynamics of development. It is the place where entities representing the demand and supply of transport services meet. Companies that are different in terms of the profile and scope of their activities function 
on this market. The market of transport services provides proper conditions necessary to manufacture, sell and purchase transport services. The purpose of the article is to analyze the market of transport services in terms of the complexity of its structure as well as the impact on the companies' management processes. Particular attention was paid to the service structure of the road transport sector.

\section{Essence and significance of transport services in companies' management processes}

Transport services result from needs reported by the participants of the transport market. The essence of these services is to satisfy the needs of buyers related to the implementation of the transportation process. The transportation process is not limited only to the service of movement but is also related to additional services, such as: the organization of transport or loading-unloading, when cargo is transported. These actions not only determine the execution of transportation itself but also provide for its execution under conditions adequate to the transport susceptibility of a given cargo (Ciesielski, 2005, p. 34). In addition, it is necessary to conduct a number of additional actions related to the preparation of the cargo and the means of transport as well as other actions that will ensure an efficient and safe service. It should be pointed out that the transport service is the basic service provided by entities operating on the market of transport services. It consists in performing transport tasks that result in the movement of people or cargo for a fee. It should be emphasized that the sector of transport services is perceived as one of the most important sections of the economy because no production-service processes may take place without involving transport. In addition, transport services may be characterized by a high level of complexity, both in technical and organizational terms. That is why various branches, systems and forms of transport are used to satisfy the needs of customers (Mendyk, 2009; p. 12, Rydzkowski, Wojewódzka-Król, 2006, p. 30; Tomanek, 2004, p. 27). Transport services are very significant in the activities conducted by companies. They are the basis for an efficient flow of materials used in the production process and the flow of final products to recipients. Transport services integrate the company's production system with the area of deliveries, sales and production. This means that they combine elements of the production and the service system as well as enable the flow of products between them. Therefore, they contribute to the improvement in the movement of materials and then final products, namely to the improvement in the level of deliveries. The significance of transport in the companies' management processes is tremendous because it improves their performance, particularly relations with the market environment, with regard to both suppliers and recipients. Transport services are an important factor affecting a company's competitiveness. They make it possible to ensure efficient logistics services as well as a lower level of material provisions, and thus affect the quality of customer service.

\section{Subjective branch structure of the transport market}

The market of transport services is the place where the demand for and supply of transport service meet and a form of their confrontation. Its participants communicate with one another which results in purchase-sales transactions of services (Rucińska, 2012, p. 17). Carriers, operators and organizers of transport of various branches and systems of transport operation meet there. Services on the transport market are provided by companies with a various scope of offers, scope of operation and size. Both large and small companies function on this market, companies providing diversified services, starting from a typical transport service, through shipping, storage, packaging and customizing, packing, to a complex service for entire supply chains on the domestic and international scale. 
The fundamental element of the existence and the functioning of the transport market is the whole of relations of service exchange between sellers and buyers, namely service providers and customers. Service providers are represented by entities providing and organizing transport services, and customers include the users of transport, namely passengers and people purchasing the services of cargo transportation.

The market of transport services is a complex structure whose efficiency of operation depends on the integration of systems: physical movement, information flow, payments and general conditions for concluding transactions. It performs various functions: realization, information, integrating, verifying as well as creates other markets (Flejterski, Panasiuk, Perenc, Rosa, 2005, pp. 149-156). However, the basic function is the movement, called the realization function. The market of transport services has specific characteristics resulting from its autonomy in structural, technical-technological and organizational terms. Its most important distinguishing mark is the turnover of movement services as well as its complementary nature towards other markets. Buyers of transport services also vary among one another, e.g. by the level of the consumption of services, expectations regarding their quality, the level of prices etc. This results in the fact that not all transport companies are able to handle all potential buyers because this requires a high level of specialization as well as financial resources to a large extent. Companies are usually able to handle one or several market segments, and this depends on their size as well as on the structure of the market on which they function. This creates the conditions for the existence of the monopoly of services supply on transport market. This means that on the supply side function only one manufacturer and provider of transport services and on the demand side many recipients with various quantitative and qualitative needs On the transport market, companies which subordinate both the specific group of carriers and types of markets can obtain the monopoly. Companies transporting gas, liquid fuels etc. may be an example. Another type of monopoly is a natural monopoly service provider. It is the result of the occurrence of barriers to entry the market, usually associated with very high investment costs for the construction and maintenance of the infrastructure, for example railway companies are characterized by a monopoly position in the field of railway network.

The market of transport services is also characterized by the fact that it has no permanent service offer which results in the fact that service providers offer only the readiness to perform the service. This readiness is characterized by a very high level of preparation to execute transport services as well as the synchronization of actions and functions of all market participants. The supply side on the market of transport services is represented by companies providing transport services in the functional-subjective meaning (Rucińska, 2012, p. 24). They include companies that conduct their own transport activities or have a license to handle transport on partial markets (Table 1). The supply side is also represented by companies and institutions cooperating with carriers or creating transport policies. They include offices, chambers and trade associations (Rucińska, 2012, p. 25).

The presented division of entities operating on the market of transport services indicates the fact that they may be classified in terms of various criteria. However, the basic criteria are the object of transportation and the branch of transport. These two criteria determine the use of adequate means of transport as well as infrastructural devices and objects. It results from the fact that each branch of transport has its specific characteristics and properties of the technical-operational, organizational-legal and economic nature. Another important criterion is also division of companies due to the availability of their services for the user. This criterion results in the fact that public, trade and own transport is distinguished. At this point, it is worth emphasizing that the traditional branch presentation of transport is no longer popular at present (Marciniak-Neider, Neider, 2006). This means that customers aim at obtaining complex services provided by one contractor and organizer. This results in the fact that the market of 
transport services includes companies with a wide range of their profile of operation, serving as logistic operators, namely entities integrating transport services.

Table 1. Basic characteristics of entities operating on the market of transport services

\begin{tabular}{ll}
\hline \multicolumn{1}{c}{ Criterion of division } & \multicolumn{1}{c}{ Type of company } \\
\hline Object of transportation & - transport of people (passenger transport companies) \\
& - transport of cargo (cargo transport companies) \\
\hline Division of branches & - vehicle transport companies \\
& - railway transport companies \\
& - sea transport companies \\
& - inland water transport companies \\
& - air transport companies \\
& - state-owned \\
& - cooperative \\
& - public \\
& - private (companies, single-person companies) \\
\hline Form of ownership & - micro-companies \\
& - small companies \\
& - medium companies \\
& - large companies \\
\hline Size of company & - local companies \\
& - domestic companies \\
& - international companies \\
\hline Space of operation & - public transport companies \\
& - trade transport companies \\
& - own transport companies \\
\hline Availability of services for the user &
\end{tabular}

*Private companies, including single-person companies, operate on the basis of the Polish Act on the freedom of business activities dated July 2, 2004 according to which the company's capital is the property of its owner. These are the most frequent forms of business activities in vehicle transport.

Source: prepared by the author on the basis of: Filina-Dawidowicz, Kaup, Wiktorowska-Jasik (2014), p. 9; Koźlak (2008), p. 156.

The evolution of the transport services market is the result of changes in customer expectations concerning not only the range of services but mostly their quality. Providing high-quality transport service is a complex and difficult task, sometimes independent of the carrier. This is due to the fact that the level of quality of service is determined from specific values, which include: availability of services, distance and subject of transport, time and cost of transportation and basic postulates of transport such as duration of travel, comfort, safety and price (Tarski, 1976, p. 35). For the transport service buyer contractor selection is the result of the degree of substitution of the same services, means of transport and ways to implement the service. It should be noted that each mode of transport has a specific quality profile, which reflects the level of intensification of the features depending on use-value of service which is responsible for the competitiveness of the industry (Babis, 1986, p. 30). Moreover, the level of compliance with the requirements of the customer should be analyzed when assessing the quality of transport services.

\section{Service structure of the market of road transport}

Entities providing road transport services are the largest segment of service providers on the transport market. This advantage results not only from the size of transport production, but also from the level of sales, held assets 
and the number of employed people (it is estimated that in the sector of road transport employs approx. 240,000 people). It contains numerous entities providing transport services which strongly compete with one another. Road transport has a very complex system of legal regulations and public control due to the highest impact on the natural environment as well as a high accident rate from all branches of transport. It should be stressed, however, that this is also strongly affected by motorized individual transport (Rucińska, 2012, p. 158). That is why the demand on the market of transport services, its size, pace and directions of changes depends on numerous factors. The basic factors shaping the demand for cargo transportation include (Koźlak, 2008, p. 113):

- the level of economic development in a given region,

- the branch structure of the economy,

- the distribution and organization of business activities, including trade and distribution of products and services,

- the specialization and technology of production.

On the other hand, demand for transport services in passenger transportation mostly results from (Koźlak, 2008, p. 114):

- the demography - the number of people, the distribution and concentration of settlements,

- the level of professional activities,

- the wealth of the society, its purchasing power and lifestyle,

- the structure of the costs of individual and public transport,

- the availability, the level of time competitiveness and the quality of public transport services etc.

The listed factors indicate the fact that the demand for road transport services is not uniform. It is characterized by a diverse level of presence, and thus services in this sector of transport are the most extensive ones. This results from its generality as well as the function supporting other branches of transport, mainly with regard to deliverydispatch services. Segments of services provided by entities operating in the road transport sector include:

- the transportation of cargo with diverse transport susceptibility on domestic and international routes in the system "door to door",

- services being a component of intermodal and multimodal systems,

- services provided for other branches of transport with regard to terminal services,

- the transportation of cargo requiring specialized rolling stock, e.g. the transportation of liquid, cooling/ cooled cargo etc.,

- services requiring the application of rolling stock equipped with specialized loading-unloading equipment, e.g. HDS,

- the transportation of oversize cargo,

- courier services.

On the other hand, the sector of road transport is characterized by the provision of services in the following segments in the transport of people:

- international coach and bus transport,

- long-distance domestic coach and bus transport,

- local and regional (including in agglomerations, cities and in rural areas) coach and bus transport,

- individual taxi transport. 
Road transport makes it possible to provide cargo or passenger transport services directly to the destination as the only branch of transport. That is why it is the most important element of each transport system. It is responsible for the majority of transportation workload, its share is estimated at as much as $45 \%$ of all transport. Polish road transport in 2014 was responsible for the movement of 1,547,883,000 tons of cargo, and passenger transported amounted to 431,192,000 people (without municipal transport - Table 2).

Table 2. Transport of cargo and passengers by road transport in Poland in 2014

\begin{tabular}{lc}
\hline & Transport of cargo (in thousands of tons) \\
\hline In total & $1,547,883$ \\
In domestic transport & $1,107,702$ \\
In international transport & 192,680 \\
\hline \multicolumn{1}{c}{ Passenger transport (in thousands of passengers) } \\
\hline In total & 431,192 \\
In domestic transport & 39,937 \\
In international transport & 3,255 \\
\hline
\end{tabular}

Source: prepared by the author on the basis of: Transport... (2015).

At this point, we should point out that the shaping of two different tendencies may be observed with regard to the segment of road passenger transport. The first one applies to passenger transport executed with the use of means of collective transport (bus and coach transport) that experienced a significant decrease in number in recent years. This situation refers both to international, domestic and extra-urban transport. A significant decrease in the group of transport extra-urban was experienced by local bus transport which resulted from the intensive development of motorized individual transport.

\section{Conclusions}

The structure of the market of transport services is the result of the participation of particular branches of transport in the transportation of cargo and passengers. Entities operating on the market of transport services are differentiated in terms of the organization, offers and technologies used for transport as well as the methods of providing services. This results in the need to conduct actions aimed at the synchronization and coordination of the functions of all entities, regardless of the branch of transport. The disproportion on the part of the share of road transport in total transportation is visible on the Polish market of transport services, like in other European countries. This results from numerous factors, but one of the most significant ones is the high level of generality of this branch of transport which makes it possible to quickly adjust the offer to changing market conditions as well as to provide comprehensive services.

\section{References}

Babis, H. (1986). Kształtowanie jakości towarowych usług transportowych. Szczecin: Wydawnictwo Naukowe Uniwersytetu Szczecińskiego.

Ciesielski, M. (ed.) (2005). Rynek usług logistycznych. Warszawa: Difin.

Filina-Dawidowicz, L., Kaup, M., \& Wiktorowska-Jasik, A. (2014). Zintegrowany transport wodny i lądowy. Szczecin: Wydawnictwo Uczelniane Zachodniopomorskiego Uniwersytetu Technologicznego w Szczecinie. 
Flejterski, S., Panasiuk, A., Perenc, J., \& Rosa, G. (eds.) (2005). Współczesna ekonomika usług. Warszawa: Wydawnictwa Naukowe PWN.

Koźlak, A. (2008). Ekonomika transportu. Teoria i praktyka gospodarcza. Gdańsk: Wydawnictwo Uniwersytetu Gdańskiego.

Marciniak-Neider, D., \& Neider, J. (2006). Podręcznik spedytora. Polska Izba Spedycji i Logistyki.

Mendyk, E. (2009). Ekonomika transportu. Poznań: Wyższa Szkoła Logistyki.

Rucińska, D. (ed.) (2012). Polski rynek usług transportowych. Warszawa: Polskie Wydawnictwo Ekonomiczne.

Rydzkowski, W. \& Wojewódzka-Król, K. (2006). Transport. Problemy transportu w rozszerzonej UE. Warszawa: Wydawnictwo Naukowe PWN.

Tarski, I. (1976). Czynnik czasu w procesie transportowym. Warszawa: Wydawnictwa Komunikacji i Łączności.

Tomanek, R. (2004). Funkcjonowanie transportu. Katowice: Wydawnictwo Akademii Ekonomicznej im. Karola Adamieckiego w Katowicach.

Transport - wyniki działalności w 2014 r. (2015). Warszawa: GUS.

Cite this article aS: Wiktorowska-Jasik, A. (2016). Market of transport services - attempt at structural-functional identification. European Journal of Service Management, 18 (2), 55-61. DOI: 10.18276/ejsm.2016.18-07. 
